\title{
High quality draft genome sequence of Janthinobacterium psychrotolerans sp. nov., isolated from a frozen freshwater pond
}

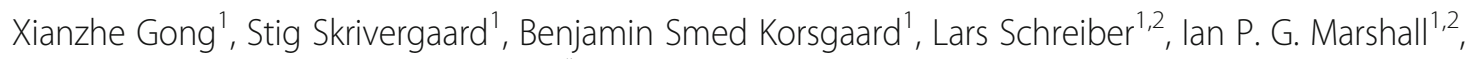
Kai Finster ${ }^{1,3}$ and Andreas Schramm ${ }^{1,2^{*}}$

\begin{abstract}
Strain S3-2 ${ }^{\top}$, isolated from sediment of a frozen freshwater pond, shares 99\% $16 \mathrm{~S}$ rRNA gene sequence identity with strains of the genus Janthinobacterium. Strain $\mathrm{S} 3-2^{\top}$ is a facultative anaerobe that lacks the ability to produce violacein but shows antibiotic resistance, psychrotolerance, incomplete denitrification, and fermentation. The draft genome of strain S3-2 ${ }^{\top}$ has a size of $\sim 5.8 \mathrm{Mbp}$ and contains 5,297 genes, including 115 RNA genes. Based on the phenotypic properties of the strain, the low in silico DNA-DNA hybridization (DDH) values with related genomes $(<35 \%)$, and the low whole genome-based average nucleotide identity (ANI) $(<86 \%)$ with other strains within the genus Janthinobacterium, we propose that strain S3-2 ${ }^{\top}$ is the type strain (= DSM $102223=$ LMG 29653) of a new species within this genus. We propose the name Janthinobacterium psychrotolerans sp. nov. to emphasize the capability of the strain to grow at low temperatures.
\end{abstract}

Keywords: Janthinobacterium psychrotolerans, Freshwater sediment, Low temperature, Denitrification, Fermentation

\section{Introduction}

The genus Janthinobacterium includes Gram-negative, motile, aerobic rod-shaped bacteria, which were isolated from soil and aquatic environments. Production of violacein, a purple, water-insoluble, secondary metabolite, is a feature commonly found in this genus [1,2]. Violacein has anti-bacterial, anti-viral, and anti-fungal properties [3], and has even been reported to protect frogs against fungal infection, when produced by the frog skin microbiota [4].

Strain $\mathrm{S} 3-2^{\mathrm{T}}$, which is affiliated with the genus Janthinobacterium was isolated from freshwater sediment while screening for denitrifying bacteria. However, strain S3-2 $2^{\mathrm{T}}$ has traits that unambiguously distinguish it from the other strains of the genus $[2,5,6]$. Among these traits is the ability of strain $\mathrm{S} 3-2^{\mathrm{T}}$ to grow at $-3{ }^{\circ} \mathrm{C}$, and to ferment different sugars. In contrast to the other strains, strain S3-2 ${ }^{\mathrm{T}}$ does not produce the violet pigment violacein, not

\footnotetext{
* Correspondence: andreas.schramm@biology.au.dk

${ }^{1}$ Section for Microbiology, Department of Bioscience, Aarhus University, Aarhus, Denmark

${ }^{2}$ Center for Geomicrobiology, Department of Bioscience, Aarhus University,

Aarhus, Denmark

Full list of author information is available at the end of the article
}

even when grown on glycerol medium $\left(20 \mathrm{~g} \mathrm{~L}^{-1}\right)$ that induces violacein synthesis in other members of the genus Janthinobacterium. Here we present the genome of strain S3- $2^{\mathrm{T}}$ as well as its classification and phenotypic features. Taken together, these characteristics support the circumscription of $33-2^{\mathrm{T}}$ as novel species, Janthinobacterium psychrotolerans sp. nov.

\section{Organism information Classification and features}

Sediment was obtained from a small fresh water pond near Aarhus, Denmark (coordinates 56.182804 N, 10.176294 E); the pond was covered with a thick layer of ice at the time of sampling. Strain $\mathrm{S} 3-2^{\mathrm{T}}$ was isolated at room temperature under oxic conditions from a diluted sediment sample (3 $\mathrm{g}$ in $10 \mathrm{~mL}$ sterile water) by direct plating on TSB agar, containing $3 \mathrm{~g}$ tryptic soy broth (Scharlau Chemie S.A., Spain) $\mathrm{L}^{-1}, 15 \mathrm{~g}_{\text {agar } \mathrm{L}^{-1}}$.

Strain S3-2 ${ }^{\mathrm{T}}$ exhibits a 99\% $16 \mathrm{~S}$ rRNA sequence identity with Janthinobacterium agaricidamnosum (GenBank accession number: HG322949; IMG Genome ID 2585427668), the closest validly published species (Fig. 1). 


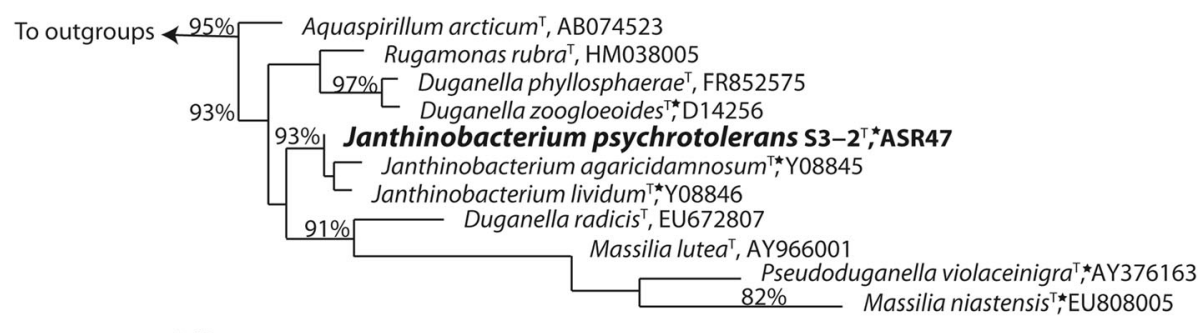

0.10

Fig. 1 Phylogenetic relationship between Janthinobacterium psychrotolerans $S 3-2^{\top}$ (shown in bold) and other closely related strains. The sequence alignment of $16 \mathrm{~S}$ rRNA genes was generated using the Ribosomal Database Project (RDP) Aligner tool [32] and manually optimized with ARB [33]. The shown maximum likelihood tree was inferred based on the General Time Reversible (GTR) model with gamma rate heterogeneity as implemented in RAxML 7.4.2 [34]. Bootstrap support (1,000 replicates) of $>70 \%$ is shown next to the branches. The genus Polymucleobacter was used to root the tree (not shown in the figure). Scale bar, 0.1 substitutions per nucleotide position. Star represents species with available sequenced genome in NCBI

Different growth temperatures $\left(-3{ }^{\circ} \mathrm{C}, 0{ }^{\circ} \mathrm{C}, 4{ }^{\circ} \mathrm{C}, 10{ }^{\circ} \mathrm{C}\right.$, $21{ }^{\circ} \mathrm{C}, 25{ }^{\circ} \mathrm{C}, 30{ }^{\circ} \mathrm{C}, 35{ }^{\circ} \mathrm{C}$, and $40{ }^{\circ} \mathrm{C}$ ) were tested on TSB plates. Growth occurred between $-3{ }^{\circ} \mathrm{C}$ and $30{ }^{\circ} \mathrm{C}$, with the optimal growth temperature being $25^{\circ} \mathrm{C}$. The range of $\mathrm{pH}$ tolerance was tested in TSB $\left(10 \mathrm{~g} \mathrm{~L}^{-1}\right)$ adjusted to $\mathrm{pH}$ values 4-9 and buffered with citric acid, phosphate, or Tris [7]. Growth occurred between $\mathrm{pH} 6$ and 8, with optimal growth at $\mathrm{pH} 7$. Salt tolerance was tested on TSB $\left(10 \mathrm{~g} \mathrm{~L}^{-1}\right)$ agar with $\mathrm{NaCl}$ concentrations ranging from $0.17 \%$ to $3.17 \%$. Strain $\mathrm{S} 3-2^{\mathrm{T}}$ tolerated up to $2.17 \%$ of $\mathrm{NaCl}$. Strain S3-2 ${ }^{\mathrm{T}}$ produced $\mathrm{N}_{2} \mathrm{O}$ (determined by an $\mathrm{N}_{2} \mathrm{O}$ sensor [8]) as the end product of denitrification in anoxic incubations with TSB containing $5 \mathrm{mM}$ nitrate; nitrite or $\mathrm{N}_{2}$ gas were never detected.

Cells of strain $\mathrm{S} 3-2^{\mathrm{T}}$ are rod-shaped, and stain Gramnegative. Cells in stationary growth phase on TSB agar were motile, and had a mean length of $1.9 \pm 0.3 \mu \mathrm{m}$, and a mean width of $0.7 \pm 0.1 \mu \mathrm{m}$ under a phase contrast microscope $(n=27)$ (Fig. 2).

Strain $\mathrm{S} 3-2^{\mathrm{T}}$ showed mucoid pale yellow colonies on TSB agar, while colonies were non-mucoid, circular with undulate margins, and orange on modified Lysogeny broth (LB) agar (10 $\mathrm{g} \mathrm{L}^{-1}$ tryptone, $5 \mathrm{~g} \mathrm{~L}^{-1}$ yeast extract, $10 \mathrm{~g} \mathrm{~L}^{-1} \mathrm{NaCl}$, $1 \%$ glycerol, $15 \mathrm{~g} \mathrm{~L}^{-1}$ agar), and brownish on glycerol medium (20 $\mathrm{g} \mathrm{L}^{-1}$ glycerol, $0.5 \mathrm{~g} \mathrm{~L}^{-1} \mathrm{NaCl}, 2.4 \mathrm{~g} \mathrm{~L}^{-1}$ $\mathrm{MgSO}_{4}, 1 \mathrm{ml} \mathrm{L}{ }^{-1}$ trace metal solution [9], $15 \mathrm{~g} \mathrm{~L}^{-1}$ agar). None of the media induced the production of violacein [10]. None of the observed pigments were fluorescent under UV light (365 nm; Vilber Lourmat, Germany).

Strain $\mathrm{S} 3-2^{\mathrm{T}}$ was resistant to penicillin (5 $\mu \mathrm{g}$ disc), and ampicillin $(10 \mu \mathrm{g}$ disc), but susceptible to streptomycin $\left(10 \mu \mathrm{g}\right.$ disc) and tetracycline $\left(30 \mu \mathrm{g}\right.$ disc) on TSB $\left(3 \mathrm{~g} \mathrm{~L}^{-1}\right)$ agar. In GEN III microplate assays (Biolog), strain S3-2 was resistant to rifamycin SV, lincomycin, and vancomycin; susceptible to niaproof 4. Strain $\mathrm{S} 3-2^{\mathrm{T}}$ did not inhibit growth of Escherichia coli K12 (DSM498; a strain resistant to penicillin, ampicillin, streptomycin, and tetracycline) on TSB (10 $\left.\mathrm{g} \mathrm{L}^{-1}\right)$ agar.
Strain S3-2 ${ }^{\mathrm{T}}$ was tested positive for alkaline phosphatase using the API ZYM test (BioMérieux, France), catalase using hydrogen peroxide, and oxidase (Bactident Oxidase, Merck, Germany). Using API 20E (BioMérieux, France), positive reactions were observed for enzymatic activity of arginine dihydrolase, for indole production, and the fermentation of D-glucose, D-mannitol, D-sucrose, and Larabinose. Negative reactions were observed for enzymatic activities of $\beta$-galactosidase, lysine decarboxylase, ornithine decarboxylase, urease, and gelatinase. Inositol, D-sorbitol, L-rhamnose, D-melibiose, and amygdalin were not fermented, and $\mathrm{H}_{2} \mathrm{~S}$ and acetoin were not produced. Janthinobacterium has previously been considered as non-fermentative $[1,11]$. The capability of linking fermentation to growth has only been reported for J. lividum strain UTB1302 with glucose [5]. Using API 20NE (BioMérieux, France), positive reactions were observed for hydrolysis of esculin ferric

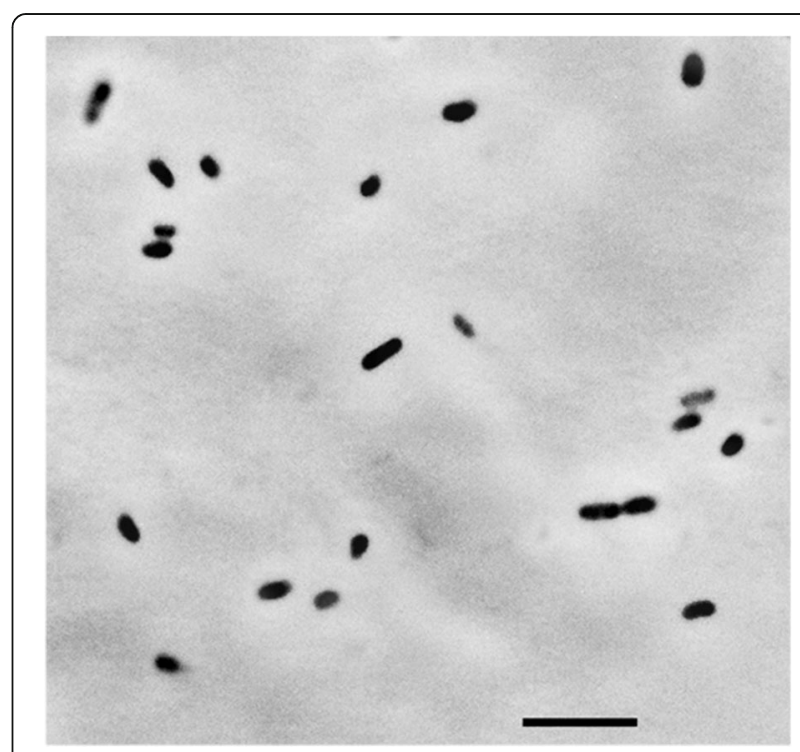

Fig. 2 Phase contrast micrograph of Janthinobacterium psychrotolerans strain $\mathrm{S} 3-2^{\top}$. Scale bar, $5 \mu \mathrm{m}$ 
citrate, and the assimilation of arabinose. Negative reactions were observed for the assimilation of D-maltose, phenylacetic acid, $\mathrm{N}$-acetyl-glucosamine, capric acid, and adipic acid. According to GEN III microplate assays (Biolog) at $25{ }^{\circ} \mathrm{C}$, strain $\mathrm{S} 3-2^{\mathrm{T}}$ could metabolize dextrin, D-cellobiose, Draffinose, $\alpha$-D-lactose, D-salicin, D-mannose, D-galactose, L-fucose, L-rhamnose, inosine, D-mannitol, D-arabitol, myo-inositol, glycyl-L-proline, L-alanine, L-aspartic acid, Lglutamic acid, L-histidine, L-pyroglutamic acid, Dgalacturonic acid, L-galacturonic acid lactone, L-lactic acid, citric acid, $\alpha$-keto-glutaric acid, D-malic acid, L-malic acid, bromo-succinic acid, Tween 40, and $\alpha$-hydroxy-butyric acid. D-maltose, D-trehalose, N-acetyl-D-galactosamine, and formic acid were not metabolized.

The generation time of strain $\mathrm{S} 3-2^{\mathrm{T}}$ was approx. $160 \mathrm{~min}$ in TSB $\left(10 \mathrm{~g} \mathrm{~L}^{-1}\right)$ with $5 \mathrm{mM}$ nitrate when grown aerobically at $20^{\circ} \mathrm{C}$. Overall, strain $\mathrm{S} 3-2^{\mathrm{T}}$ has traits that unambiguously distinguish it from other strains of the genus $[2,5,6]$. Among these traits is the ability of strain $\mathrm{S} 3-2^{\mathrm{T}}$ to grow at $-3{ }^{\circ} \mathrm{C}$. In contrast to the other strains, strain $\mathrm{S} 3-2^{\mathrm{T}}$ does not produce the pigment violacein, not even when grown on glycerol medium $\left(20 \mathrm{~g} \mathrm{~L}^{-1}\right)$, which induces violacein synthesis in other members of the genus Janthinobacterium [10]. Strain $\mathrm{S} 3-2^{\mathrm{T}}$ is available from the Belgian Co-ordinated Collection of Micro-organisms BCCM/LMG Bacteria Collection as strain LMG 29653 and the Leibniz Institute DSMZ - German Collection of Microorganisms and Cell Cultures as strain DSM 102223; its general properties are summarized in Table 1.

\section{Genome sequencing information Genome project history}

The draft genome sequence of strain $\mathrm{S} 3-2^{\mathrm{T}}$ was completed on December 21, 2015. The genome project is deposited in the Genomes OnLine Database (GOLD) as project Gp0124039. This Whole Genome Shotgun project has been deposited at GenBank under the accession LOCQ00000000. The version described in this paper is version LOCQ01000000. The summarized information of this project is shown in Table 2 .

\section{Growth conditions and genomic DNA preparation}

Strain S3-2 ${ }^{\mathrm{T}}$ was grown at $25{ }^{\circ} \mathrm{C}$ in TSB $\left(10 \mathrm{~g} \mathrm{~L}^{-1}\right)$ supplemented with $5 \mathrm{mM}$ nitrate. The cells were harvested by centrifugation and DNA was extracted from the pellet using the PowerLyser ${ }^{\circ}$ PowerSoil $^{\circ}$ DNA extraction kit (MoBio, Carlsbad, CA, USA) according to the manufacturer's protocol.

\section{Genome sequencing and assembly}

The genome of strain $\mathrm{S} 3-2^{\mathrm{T}}$ was sequenced with the Illumina MiSeq Reagent Kit V3 (Illumina Inc. San Diego, CA, USA). Sequencing libraries were prepared using the Nextera XT Library Preparation Kit (Illumina). The
Table 1 Classification and general features of Janthinobacterium psychrotolerans S3-2 $2^{\top}[35]$

\begin{tabular}{|c|c|c|c|}
\hline MIGS ID & Property & Term & Evidence code $^{a}$ \\
\hline & Classification & Domain Bacteria & TAS [36] \\
\hline & & Phylum Proteobacteria & TAS [37] \\
\hline & & Class Betaproteobacteria & TAS [38] \\
\hline & & Order Burkholderiales & TAS [39] \\
\hline & & Family Oxalobacteraceae & TAS [40] \\
\hline & & Genus Janthinobacterium & TAS [40] \\
\hline & & $\begin{array}{l}\text { Species Janthinobacterium } \\
\text { psychrotolerans }\end{array}$ & TAS [40] \\
\hline & & $\begin{array}{l}\text { Strain S3-2 } \\
(\text { LMG } 29653=\text { DSM 102223) }\end{array}$ & IDA \\
\hline & Gram stain & Negative & IDA \\
\hline & Cell shape & Rod & IDA \\
\hline & Motility & Motile & $\mathrm{IDA}$ \\
\hline & Sporulation & None & IDA \\
\hline & $\begin{array}{l}\text { Temperature } \\
\text { range }\end{array}$ & $-3{ }^{\circ} \mathrm{C}-30^{\circ} \mathrm{C}$ & IDA \\
\hline & $\begin{array}{l}\text { Optimum } \\
\text { temperature }\end{array}$ & $25^{\circ} \mathrm{C}$ & IDA \\
\hline & $\begin{array}{l}\text { pH range; } \\
\text { Optimum }\end{array}$ & $6-8 ; 7$ & IDA \\
\hline & Carbon source & $\begin{array}{l}\text { Sugars, amino acids, } \\
\text { fatty acids etc. }\end{array}$ & IDA \\
\hline MIGS-6 & Habitat & Freshwater sediment & IDA \\
\hline MIGS-6.3 & Salinity & $0.17-2.17 \% \mathrm{NaCl}(\mathrm{w} / \mathrm{v})$ & IDA \\
\hline MIGS-22 & $\begin{array}{l}\text { Oxygen } \\
\text { requirement }\end{array}$ & Facultative anaerobic & IDA \\
\hline MIGS-15 & $\begin{array}{l}\text { Biotic } \\
\text { relationship }\end{array}$ & Free-living & IDA \\
\hline MIGS-14 & Pathogenicity & Unknown & IDA \\
\hline MIGS-4 & $\begin{array}{l}\text { Geographic } \\
\text { location }\end{array}$ & Aarhus, Denmark & IDA \\
\hline MIGS-5 & $\begin{array}{l}\text { Sample } \\
\text { collection }\end{array}$ & 2015-01-16 & IDA \\
\hline MIGS-4.1 & Latitude & $56^{\circ} 10^{\prime} 58.1 " \mathrm{~N}$ & IDA \\
\hline MIGS-4.2 & Longitude & $10^{\circ} 10^{\prime} 34.7^{\prime \prime} \mathrm{E}$ & IDA \\
\hline MIGS-4.4 & Altitude & $70 \mathrm{~m}$ & IDA \\
\hline
\end{tabular}

${ }^{a}$ Evidence codes - IDA: Inferred from Direct Assay; TAS: Traceable Author Statement (i.e., a direct report exists in the literature); NAS: Non-traceable Author Statement (i.e., not directly observed for the living, isolated sample, but based on a generally accepted property for the species, or anecdotal evidence). These evidence codes are from the Gene Ontology project [41]

sequencing library produced 3,761,645 paired end reads totalling $\sim 2.11 \mathrm{Gbp}$. In total, 2,868,634 reads remained after quality trimming and adapter removal with Trimmomatic$0.33[12]$ and the following trimming parameters: CROP:235 HEADCROP:25 SLIDINGWINDOW:4:20. Read quality before and after trimming was assessed by FastQC version 0.11.4 [13]. The trimmed reads ( 1.04 Gbp) represented an average genome coverage of $\sim 178$-fold based on 
Table 2 Project information

\begin{tabular}{|c|c|c|}
\hline MIGS ID & Property & Term \\
\hline MIGS 31 & Finishing quality & High quality draft \\
\hline MIGS-28 & Libraries used & $\begin{array}{l}\text { NexteraXT DNA } \\
\text { sample preparation }\end{array}$ \\
\hline MIGS 29 & Sequencing platforms & Illumina MiSeq \\
\hline MIGS 31.2 & Fold coverage & 178 \\
\hline MIGS 30 & Assemblers & SPAdes 3.6.1 \\
\hline \multirow[t]{6}{*}{ MIGS 32} & Gene calling method & Prodigal v2.6.2 \\
\hline & Locus Tag & ASR47 \\
\hline & Genbank ID & LOCQ00000000 \\
\hline & $\begin{array}{l}\text { GenBank Date } \\
\text { of Release }\end{array}$ & 2017-01-31 \\
\hline & GOLD ID & Gp0124039 \\
\hline & BIOPROJECT & PRJNA300713 \\
\hline \multirow[t]{2}{*}{ MIGS 13} & $\begin{array}{l}\text { Source Material } \\
\text { Identifier }\end{array}$ & LMG 29653, DSM 102223 \\
\hline & Project relevance & Environmental, denitrification \\
\hline
\end{tabular}

the size of the assembled draft genome of strain $S 3-2^{\mathrm{T}}$. Reads were assembled using SPAdes 3.6.1 [14]. Contigs shorter than 1,000 bp were removed after the assembly.

\section{Genome annotation}

The draft genome was annotated using the standard operation procedure of the DOE-JGI Microbial Genome Annotation Pipeline (MGAP v.4) supported by the JGI (Walnut Creek, CA; USA) [15]. Briefly, CRISPR elements were determined by the programs CRT [16] and PILERCR v1.06 [17]. Non-coding RNAs, and tRNAs, were predicted by tRNAscan-SE 1.3.1 [18]. rRNA genes were identified by HMMER 3.1b2 [19]. Protein-coding genes were determined by Prodigal v2.6.2 [20]. Functional annotation was based on assigning the genes to different databases: the COG \& KOG database (November, 2014) [21], the KEGG database (release 71.0, July 2014) [22], the MetaCyc database (release 18.1, June 2014) [23], the Pfam database (version 28.0, May, 2015) [24], the TIGRfam database (release 14.0, January, 2014) [25], and the InterPro Scan database (release 48) [26]. In silico DNA-DNA hybridization (GGDC 2.0) was carried out with the online genome-to-genome calculator provided by the DSMZ [27].

\section{Genome properties}

The properties of the draft genome of strain $\mathrm{S} 3-2^{\mathrm{T}}$ are summarized in Table 3, and the assignment of genes into COG functional categories is shown in Table 4. The assembled draft genome features a G + C content of $63.04 \mathrm{~mol} \%$, and consists of 62 contigs ranging in size from 1,026 bp to $498,889 \mathrm{bp}$ and totalling 5,844,062 bp. Based on CheckM 1.0.3 [28] in concert with conserved single copy genes detected in four reference genomes of Janthinobacterium
Table 3 Genome statistics

\begin{tabular}{lll}
\hline Attribute & Value & \% of Total \\
\hline Genome size (bp) & $5,844,062$ & 100 \\
DNA coding (bp) & $5,291,400$ & 90.54 \\
DNA G + C (bp) & $3,683,895$ & 63.04 \\
DNA scaffolds & 62 & 100 \\
Total genes & 5,297 & 100 \\
Protein coding genes & 5,182 & 97.83 \\
RNA genes & 115 & 2.17 \\
Pseudo genes & 0 & 0 \\
Genes in internal clusters & 639 & 12.06 \\
Genes with function prediction & 4,087 & 77.16 \\
Genes assigned to COGs & 3,543 & 66.89 \\
Genes with Pfam domains & 4,291 & 81.01 \\
Genes with signal peptides & 724 & 13.67 \\
Genes with transmembrane helices & 1,275 & 24.07 \\
CRISPR repeats & 0 & 0
\end{tabular}

spp. or 5,449 bacterial genomes, the genome of strain S3$2^{\mathrm{T}}$ was estimated to be $98.28 \%$ or $95.69 \%$ complete, respectively. There are 5,182 (97.83\%) protein-coding genes and 115 RNAs of the 5,297 predicted genes. Of the RNA, 77 are tRNAs and 25 are rRNAs. Based on the number of 5S, and partial $16 \mathrm{~S}$ and $23 \mathrm{~S}$ rRNA genes, the genome features at least 8 rRNA operons. Putative functions were assigned to $77.08 \%$ of the protein-coding genes.

\section{Insights from the genome sequence}

There is a high $16 \mathrm{~S}$ rRNA sequence identity of $99 \%$ between strain $\mathrm{S} 3-2^{\mathrm{T}}$ and all other strains with validly published names within the genus Janthinobacterium (Table 5). This value is higher than the $98.7 \%$ identity threshold recommended by Meier-Kolthoff et al. [29] to propose a new species within the phylum Proteobacteria. Therefore, in silico DNA-DNA hybridization (DDH) against reference genomes was performed using the online genome-togenome calculator with the GGDC 2.0 BLAST+ model [27]. DDH values calculated according to formula 2 (to confidently predict DDH values of incomplete genomes [27]) were always $<35 \%$ (Table 5 , and Additional file 1 : Table S1), and thus clearly below the $70 \%$ threshold to differentiate bacterial species [27]. Whole-genome-based average nucleotide identities (ANI) to other Janthinobacterium genomes were calculated by the online tool [30, 31]. ANI was always $<86 \%$ (Table 5 , and Additional file 1 : Table S2) [30], and thus also well below the threshold for species delineation (95\%; [31]). Hence, both results support the phenotypic distinction of strain $\mathrm{S} 3-2^{\mathrm{T}}$ as novel species within the genus Janthinobacterium.

Violacein production, a common feature in Janthinobacterium, was never observed in growth studies with strain 
Table 4 Number of genes associated with general COG functional categories

\begin{tabular}{|c|c|c|c|}
\hline Code & Value & \%age & Description \\
\hline J & 217 & 5.35 & $\begin{array}{l}\text { Translation, ribosomal structure } \\
\text { and biogenesis }\end{array}$ \\
\hline A & 1 & 0.02 & RNA processing and modification \\
\hline K & 338 & 8.33 & Transcription \\
\hline L & 119 & 2.93 & Replication, recombination and repair \\
\hline B & 2 & 0.05 & Chromatin structure and dynamics \\
\hline D & 36 & 0.89 & $\begin{array}{l}\text { Cell cycle control, Cell division, } \\
\text { chromosome partitioning }\end{array}$ \\
\hline V & 105 & 2.59 & Defense mechanisms \\
\hline $\mathrm{T}$ & 336 & 8.28 & Signal transduction mechanisms \\
\hline M & 268 & 6.61 & Cell wall/membrane biogenesis \\
\hline $\mathrm{N}$ & 183 & 4.51 & Cell motility \\
\hline$U$ & 87 & 2.14 & Intracellular trafficking and secretion \\
\hline O & 182 & 4.49 & $\begin{array}{l}\text { Posttranslational modification, } \\
\text { protein turnover, chaperones }\end{array}$ \\
\hline C & 221 & 5.45 & Energy production and conversion \\
\hline G & 256 & 6.31 & Carbohydrate transport and metabolism \\
\hline E & 309 & 7.62 & Amino acid transport and metabolism \\
\hline $\mathrm{F}$ & 87 & 2.14 & Nucleotide transport and metabolism \\
\hline $\mathrm{H}$ & 190 & 4.68 & Coenzyme transport and metabolism \\
\hline I & 174 & 4.29 & Lipid transport and metabolism \\
\hline$P$ & 232 & 5.72 & Inorganic ion transport and metabolism \\
\hline Q & 87 & 2.14 & $\begin{array}{l}\text { Secondary metabolites biosynthesis, } \\
\text { transport and catabolism }\end{array}$ \\
\hline $\mathrm{R}$ & 331 & 8.16 & General function prediction only \\
\hline S & 233 & 5.74 & Function unknown \\
\hline - & 1754 & 33.11 & Not in COGs \\
\hline
\end{tabular}

The total is based on the total number of protein coding genes in the genome

S3-2 $2^{\mathrm{T}}$. This observation is consistent with the absence of the vioABCDE operon, which encodes the genes required for the synthesis of this pigment; neither the automated annotation nor manual BLAST searches of the S3-2 $2^{\mathrm{T}}$ genome for known components of the vioABCDE operon (Additional file 1: Table S3) [2, 6] identified any genes encoding violacein synthesis.

The genome of strain $\mathrm{S} 3-2^{\mathrm{T}}$ features all necessary genes for nitrate reduction to $\mathrm{N}_{2} \mathrm{O}$ but lacks genes encoding the nitrous oxide reductase (Additional file 1: Table S4), which is consistent with $\mathrm{N}_{2} \mathrm{O}$ as end-product of denitrification. Genes affiliated with aerobic respiration were identified, including terminal oxidases with both high- and lowaffinity for oxygen (Additional file 1: Table S5). Another characteristic of strain $\mathrm{S} 3-2^{\mathrm{T}}$ is its capability to ferment different sugars, a trait which has not been reported for other strains in the genus Janthinobacterium $[1,5,11]$. The genes that encode these properties were summarized (Additional file 1: Table S6, and Figure S1).
Table 5 Sequence similarity of J. psychrotolerans strain $\mathrm{S} 3-2^{\top}$ with described species of the genus Janthinobacterium

\begin{tabular}{llll}
\hline Strain name & $\begin{array}{l}\text { 16S rRNA } \\
\text { identity (\%) }\end{array}$ & $\begin{array}{l}\text { DDH (Model-based } \\
\text { Confidence Interval) (\%) }\end{array}$ & ANI \pm SD $^{\mathrm{b}}(\%)$ \\
\hline $\begin{array}{l}\text { Janthinobacterium } \\
\text { agaricidamnosum }\end{array}$ & 99 & $23.3(21.0-25.7)$ & $81.66 \pm 5.07$ \\
$\begin{array}{l}\text { Janthinobacterium } \\
\text { lividum MTR }\end{array}$ & 98 & $28.0(25.6-30.5)$ & $84.69 \pm 4.73$ \\
$\begin{array}{l}\text { Janthinobacterium } \\
\text { lividum NFR18 }\end{array}$ & 99 & $27.7(25.3-30.2)$ & $84.73 \pm 4.87$ \\
$\begin{array}{l}\text { Janthinobacterium } \\
\text { lividum PMC 25724 }\end{array}$ & 99 & $26.6(24.3-29.1)$ & $83.84 \pm 4.58$ \\
$\begin{array}{l}\text { Janthinobacterium } \\
\text { lividum RIT308 }\end{array}$ & 99 & $27.9(25.5-30.4)$ & $84.75 \pm 4.84$ \\
\hline
\end{tabular}

${ }^{2}$ Values for $16 \mathrm{~S}$ rRNA identity are based on BLAST of the S3-2 ${ }^{\top} 16 \mathrm{~S}$ rRNA gene against genomes in IMG, except for J. lividum MTR, which was retrieved from NCBI (acc. nr. JQ070957.1)

${ }^{\mathrm{b}} \mathrm{SD}$ : Standard Deviation

\section{Conclusions}

Based on the phenotypic properties, phylogenetic position, and whole genome comparison, we formally propose strain S3-2 ${ }^{\mathrm{T}}$ as novel species of the genus Janthinobacterium, for which we propose the name Janthinobacterium psychrotolerans sp. nov. with strain S3-2 ${ }^{\mathrm{T}}$ (=DSM $102223=$ LMG 29653) as the type strain.

\section{Description of Janthinobacterium psychrotolerans sp. nov.}

Janthinobacterium psychrotolerans (psy.chro.to'le.rans. Gr. adj. psychros cold; L. part. adj. tolerans tolerating; N.L. neut. part. adj. psychrotolerans tolerating cold temperatures).

Janthinobacterium psychrotolerans is a facultative anaerobic, Gram-negative bacterium. Cells are rod-shaped, motile, and have a size of $1.9 \pm 0.3 \times 0.7 \pm 0.1 \mu \mathrm{m}$. Colonies are pale yellow and mucoid on TSB agar. Growth occurs between -3 and $30^{\circ} \mathrm{C}$, with optimal growth observed at $25{ }^{\circ} \mathrm{C}$. Strain $\mathrm{S} 3-2^{\mathrm{T}}$ tolerates salinity between $0.17 \%$ and $2.17 \% \mathrm{NaCl}$, and grows within the $\mathrm{pH}$ range of 6 to 8 with optimal growth observed at $\mathrm{pH} 7$.

Positive for catalase, oxidase, alkaline phosphatase, arginine dihydrolase. Negative for $\beta$-galactosidase, lysine decarboxylase, ornithine decarboxylase, urease, gelatinase.

Positive for metabolizing dextrin, D-cellobiose, Draffinose, $\alpha$-D-lactose, D-salicin, D-mannose, D-galactose, Lfucose, L-rhamnose, inosine, D-mannitol, D-arabitol, myoinositol, glycyl-L-proline, L-alanine, L-aspartic acid, Lglutamic acid, L-histidine, L-pyroglutamic acid, Dgalacturonic acid, L-galacturonic acid lactone, L-lactic acid, citric acid, $\alpha$-keto-glutaric acid, D-malic acid, L-malic acid, bromo-succinic acid, Tween 40 , and $\alpha$-hydroxy-butyric acid. Negative for metabolizing D-maltose, D-trehalose, $\mathrm{N}$-acetylD-galactosamine, and formic acid. 
Positive for hydrolysis of esculin ferric citrate, assimilation of arabinose, and indole production. Negative for assimilation of D-maltose, phenylacetic acid, $\mathrm{N}$-acetyl-glucosamine, capric acid, and adipic acid, acetoin production, and $\mathrm{H}_{2} \mathrm{~S}$ production.

Strain $\mathrm{S} 3-2^{\mathrm{T}}$ is able to ferment D-glucose, D-mannitol, $\mathrm{D}$-sucrose, and L-arabinose; unable to ferment inositol, D-sorbitol, L-rhamnose, D-meliblose, and amygdalin.

Resistant to penicillin, vancomycin, rifamycin SV, lincomycin, and ampicillin; susceptible to streptomycin, niaproof 4 , and tetracycline.

The $\mathrm{G}+\mathrm{C}$ content of the genome is $63.04 \mathrm{~mol} \%$. The genome project is deposited in the Genomes OnLine Database (GOLD) as project Gp0124039. This Whole Genome Shotgun project is deposited at GenBank under the accession LOCQ00000000. The type strain $\mathrm{S} 3-2^{\mathrm{T}}$ (= LMG 29653 = DSM 102223) was isolated from sediment of a small, frozen pond in Hasle, Aarhus, Denmark (coordinates 56.182804 N, 10.176294 E) in January, 2015.

\section{Additional file}

\section{Additional file 1: Table S1. Results of in silico DNA-DNA hybridization} (DDH) of the assembled strain S3-2 draft genome against all published Janthinobacterium genomes using the online genome-to-genome calculator with the GGDC 2.0 BLAST+ model [1]. Displayed values were calculated according to formula 2, the only formula able to confidently predict DDH values of incomplete genomes [1]. The threshold to delineate two distinct species is 70\% [1]. Table S2. Whole genome-based average nucleotide identity (ANI) of strain S3-2 to other sequenced Janthinobacterium genomes $[2,3]$. The threshold to delineate two distinct species is 95\% [3]. Table S3. Locus tags of the vioABCDE operon in other Janthinobacterium genomes in IMG. Table S4. Genomic inventory for denitrification in strain S3-2 based on the annotation from IMG. Table S5. Genomic inventory for terminal oxidases in strain S3-2 based on the annotation from IMG. Table $\mathbf{5 6}$. Genes encoding the D-Glucose fermentation pathway in strain S3-2 based on the annotation from IMG. Figure S1. Pathway of D-Glucose fermentation in strain S3-2 based on the annotation from IMG. (1), glucokinase; (2), glucose-6-phosphate isomerase; (3), 6-phosphofructokinase 1; (4), fructose-bisphosphate aldolase; (5), triosephosphate isomerase; (6), glyceraldehyde 3phosphate dehydrogenase; (7), phosphoglycerate kinase; (8), 2,3-bisphosphoglycerate-dependent phosphoglycerate mutase; (9), probable phosphoglycerate mutase; $(10)$, enolase; $(11,12)$, pyruvate kinase; $(13,14)$, pyruvate dehydrogenase (quinone); (15, 16), L-lactate dehydrogenase (cytochrome). For gene details, see Table S5. (DOCX $41 \mathrm{~kb})$

\section{Abbreviations}

ANI: Average nucleotide identities; DDH: DNA-DNA hybridization; GOLD: Genomes OnLine database; GTR: General time reversible; LB: Lysogeny broth; MGAP: Microbial genome annotation pipeline; RDP: Ribosomal database project; TSB: Tryptic soy broth.

\section{Acknowledgements}

We thank Anne B. Stentebjerg, Britta Poulsen, Trine B. Søgaard, Lars B. Pedersen, Preben G. Sørensen, and Lars R. Damgaard for excellent technical assistance. This study was supported by the Danish National Research Foundation (grants no. DNRF104), the European Research Council (grants no. 267233 and 294200), the Graduate School of Science and Technology, Aarhus University, Denmark, and the Department of Bioscience, Aarhus University.

\section{Authors' contributions}

KF and AS designed research; SS and BSK isolated and characterized strain S3-2 ${ }^{\top}$; XG carried out the genome sequencing and additional strain characterization; $X G$,
$L S$, and IM performed bioinformatics analyses; all authors analysed data; $X G, A S$, and KF wrote the manuscript; all authors read and approved the final manuscript.

\section{Competing interests}

The authors declare that they have no competing interests.

\section{Author details}

'Section for Microbiology, Department of Bioscience, Aarhus University, Aarhus, Denmark. ${ }^{2}$ Center for Geomicrobiology, Department of Bioscience, Aarhus University, Aarhus, Denmark. ${ }^{3}$ Stellar Astrophysics Center, Department of Physics and Astronomy, Aarhus University, Aarhus, Denmark.

Received: 22 July 2016 Accepted: 27 November 2016

Published online: 19 January 2017

\section{References}

1. Shivaji S, Ray MK, Kumar GS, Reddy GSN, Saisree L, Wynn-Williams DD. Identification of Janthinobacterium lividum from the soils of the islands of Scotia Ridge and from Antarctic peninsula. Polar Biol. 1991;11.

2. Hornung C, Poehlein A, Haack FS, Schmidt M, Dierking K, et al. The Janthinobacterium sp. HHO1 genome encodes a homologue of the $\mathrm{V}$. cholerae CqsA and L. pneumophila LqsA autoinducer synthases. PLoS One. 2013;8(2):e55045.

3. Durán N, Justo GZ, Ferreira CV, Melo PS, Cordi L, Martins D. Violacein: properties and biological activities. Biotechnol. Appl. Biochem. 2007:48:127-33.

4. Harris RN, Brucker RM, Walke JB, Becker MH, Schwantes CR, et al. Skin microbes on frogs prevent morbidity and mortality caused by a lethal skin fungus. ISME J. 2009;3:818-24.

5. Kawakami R, Sakuraba H, Ohshima T. Gene cloning and characterization of the very large NAD-dependent I-glutamate dehydrogenase from the psychrophile Janthinobacterium lividum, isolated from cold soil. J Bacteriol. 2007:189:5626-33.

6. Schloss PD, Allen HK, Klimowicz AK, Mlot C, Gross JA, et al. Psychrotrophic strain of Janthinobacterium lividum from a cold Alaskan soil produces prodigiosin. DNA Cell Biol. 2010;29:533-41.

7. Breznak JA, Costilow RN. Physicochemical factors in growth. In: Gerhard P, Murray RGE, Wood WA, Krieg NR, editors. Methods for General and Molecular Bacteriology. Washington: American Society of Microbiology; 2007. p. 137-54.

8. Andersen $\mathrm{K}, \mathrm{Kjær} \mathrm{T}$, Revsbech NP. An oxygen insensitive microsensor for nitrous oxide. Sensors Actuators B Chem. 2001;81:42-8.

9. Widdel F, Bak F. Gram-negative mesophilic sulfate-reducing bacteria. In: Balows A, Trüper HG, Dworkin M, Harder W, Schleifer K-H, editors. The Prokaryotes. New York: Springer; 1992. p. 3352-78.

10. Pantanella F, Berlutti F, Passariello C, Sarli S, Morea C, Schippa S. Violacein and biofilm production in Janthinobacterium lividum. J Appl Microbiol. 2007;102:992-9.

11. Lincoln SP, Fermor TR, Tindall BJ. Janthinobacterium agaricidamnosum sp. nov, a soft rot pathogen of Agaricus bisporus. Int. J Syst Bacteriol. 1999;49:1577-89.

12. Bolger AM, Lohse M, Usadel B. Trimmomatic: a flexible trimmer for Illumina sequence data. Bioinformatics. 2014;30(15):2114-20.

13. Babraham Bioinformatics - FastQC. Available at: http://www.bioinformatics, babraham.ac.uk/projects/fastac/. Accessed October 20, 2015.

14. Bankevich A, Nurk S, Antipov D, Gurevich AA, Dvorkin M, et al. SPAdes: a new genome assembly algorithm and its applications to single-cell sequencing. J Comput Biol. 2012;19:455-77.

15. Huntemann M, Ivanova NN, Mavromatis K, Tripp HJ, Paez-Espino D, et al. The standard operating procedure of the DOE-JGI Microbial Genome Annotation Pipeline (MGAP v.4). Stand. Genomic Sci. 2015;10:86.

16. Bland C, Ramsey TL, Sabree F, Lowe M, Brown K, et al. CRISPR Recognition Tool (CRT): a tool for automatic detection of clustered regularly interspaced palindromic repeats. BMC Bioinformatics. 2007:8:209.

17. Edgar RC. PILER-CR: fast and accurate identification of CRISPR repeats. BMC Bioinformatics. 2007;8:18

18. Lowe TM, Eddy SR. tRNAscan-SE: A program for improved detection of transfer RNA genes in genomic sequence. Nucleic Acids Res. 1997;25:955-64.

19. Eddy SR. Accelerated profile HMM searches. PLoS Comput Biol. 2011;7(10): e1002195

20. Hyatt D, Chen G-L, Locascio PF, Land ML, Larimer FW, Hauser LJ. Prodigal: prokaryotic gene recognition and translation initiation site identification. BMC Bioinformatics. 2010;11:119. 
21. Marchler-Bauer A, Anderson JB, Derbyshire MK, DeWeese-Scott C, Gonzales $\mathrm{NR}$, et al. CDD: a conserved domain database for interactive domain family analysis. Nucleic Acids Res. 2007;35:D237-40.

22. Kanehisa M, Goto S, Sato Y, Kawashima M, Furumichi M, Tanabe M. Data information, knowledge and principle: back to metabolism in KEGG. Nucleic Acids Res. 2014;42:D199-205.

23. Caspi R, Altman T, Billington R, Dreher K, Foerster H, et al. The MetaCyc database of metabolic pathways and enzymes and the BioCyc collection of Pathway/Genome Databases. Nucleic Acids Res. 2014;42:D459-71.

24. Punta M, Coggill PC, Eberhardt RY, Mistry J, Tate J, et al. The Pfam protein families database. Nucleic Acids Res. 2012;40:D290-301.

25. Haft DH, Selengut JD, Richter RA, Harkins D, Basu MK, Beck E. TIGRFAMs and genome properties in 2013. Nucleic Acids Res. 2013;41:D387-95.

26. Jones $P$, Binns D, Chang H-Y, Fraser M, Li W, et al. InterProScan 5: genomescale protein function classification. Bioinformatics. 2014;30:1236-40.

27. Meier-Kolthoff JP, Auch AF, Klenk H-P, Göker M. Genome sequence-based species delimitation with confidence intervals and improved distance functions. BMC Bioinformatics. 2013;14:60

28. Parks DH, Imelfort M, Skennerton CT, Hugenholtz P, Tyson GW. CheckM: assessing the quality of microbial genomes recovered from isolates, single cells, and metagenomes. Genome Res. 2015: doi:10.1101/gr.186072.114.

29. Meier-Kolthoff JP, Göker M, Spröer C, Klenk H-P. When should a DDH experiment be mandatory in microbial taxonomy? Arch Microbiol. 2013;195:413-8.

30. Goris J, Konstantinidis KT, Klappenbach JA, Coenye T, Vandamme P, Tiedje JM. DNA-DNA hybridization values and their relationship to whole-genome sequence similarities. Int J Syst Evol Microbiol. 2007:57:81-91.

31. Rodriguez-R LM, Konstantinidis KT. Bypassing cultivation to identify bacterial species. Microbe Mag. 2014;9:111-8.

32. Cole JR, Wang Q, Cardenas E, Fish J, Chai B, et al. The ribosomal database project: improved alignments and new tools for rRNA analysis. Nucleic Acids Res. 2009:37:D141-5.

33. Ludwig W, Strunk O, Westram R, Richter L, Meier H, et al. ARB: a software environment for sequence data. Nucleic Acids Res. 2004;32:1363-71.

34. Stamatakis A, Hoover P, Rougemont J. A rapid bootstrap algorithm for the RAxML web servers. Syst Biol. 2008:57:758-71.

35. Field D, Garrity G, Gray T, Morrison N, Selengut J, et al. The minimum information about a genome sequence (MIGS) specification. Nat Biotechnol. 2008:26:541-7.

36. Woese CR, Kandler O, Wheelis ML. Towards a natural system of organisms: proposal for the domains Archaea, Bacteria, and Eucarya. Proc Natl Acad Sci. 1990;87:4576-9.

37. Garrity GM, Bell JA, Lilburn TE. Phylum XIV. Proteobacteria phyl. In: Garrity GM, Brenner DJ, Krieg NR, Staley JT, editors. Bergey's Manual of Systematic Bacteriology, vol. 1. 2nd ed. New York: Springer; 2005. p. 1.

38. Garrity GM, Bell JA, Lilburn TE. Class II. Betaproteobacteria. In: Garrity GM, Brenner DJ, Krieg NR, Staley JT, editors. Bergey's Manual of Systematic Bacteriology, vol. 1. 2nd ed. New York: Springer; 2005. p. 575.

39. Garrity GM, Bell JA, Lilburn TE. Order 1. Burkholderiales. In: Garrity GM, Brenner DJ, Krieg NR, Staley JT, editors. Bergey's Manual of Systematic Bacteriology, vol. 1. 2nd ed. New York: Springer; 2005. p. 575.

40. Garrity GM, Bell JA, Lilburn T. Family II. Oxalobacteraceae fam. In: Garrity GM, Brenner DJ, Krieg NR, Staley JT, editors. Bergey's Manual of Systematic Bacteriology, vol. 1. 2nd ed. New York: Springer; 2005. p. 623.

41. Ashburner M, Ball CA, Blake JA, et al. Gene ontology: tool for the unification of biology. The Gene Ontology Consortium. Nat Genet. 2000;25:25-9.

\section{Submit your next manuscript to BioMed Central and we will help you at every step:}

- We accept pre-submission inquiries

- Our selector tool helps you to find the most relevant journal

- We provide round the clock customer support

- Convenient online submission

- Thorough peer review

- Inclusion in PubMed and all major indexing services

- Maximum visibility for your research

Submit your manuscript at www.biomedcentral.com/submit

) Biomed Central 